\title{
geografia
} Malavsian Tournal of Societv and Space

\section{Penilaian kebolehupayaan pejalan kaki di Tapak Warisan Dunia UNESCO: Kajian kes di George Town, Pulau Pinang}

\author{
Mohd Sahrul Syukri Yahya ${ }^{1}$, Narimah Samat ${ }^{2}$ \\ ${ }^{1}$ Fakulti Pengurusan Teknologi dan Perniagaan, Universiti Tun Hussein Onn Malaysia \\ ${ }^{2}$ Pusat Pengajian Ilmu Kemanusiaan, Universiti Sains Malaysia \\ Correspondence: Mohd Sahrul Syukri Yahya (email: mohd.syukri1691@yahoo.com)
}

Received: 03 September 2019; Accepted: 02 February 2020; Published: 30 May 2020

\begin{abstract}
Abstrak
Kebolehupayaan pejalan kaki merupakan salah satu elemen kelestarian yang dapat memberikan pelbagai manfaat termasuk kesihatan, ekonomi dan perancangan bandar. Di Malaysia, elemen ini adalah baru dan terhad di kawasan bandar metropolitan yang maju seperti Bandaraya Kuala Lumpur, Bandaraya Johor Bahru dan Bandaraya George Town. Kini, kebolehupayaan pejalan kaki dijadikan sebagai mod pengangkutan aktif yang lestari. Tujuan kajian ini dijalankan adalah untuk mengukur dan menilai tahap indeks kebolehupayaan pejalan kaki yang dijalankan di tapak warisan dunia George Town, Pulau Pinang. Antara indikator dan data guna tanah yang digunakan adalah indeks campuran guna tanah (entropi), indeks perhubungan dan indeks nisbah bersih perniagaan (tanah komersial). Indikator ini dianalisis, dinilai dan diintergrasikan dengan aplikasi Sistem Maklumat Geografi untuk penghasilan peta indeks kebolehupayaan pejalan kaki. Bagi mendapatkan penilaian indeks kebolehupayaan pejalan kaki yang jitu, kaedah pengesahan di lapangan dijalankan dengan kaedah temubual di setiap lokasi tertentu. Hasil dapatan kajian ini mendapati kawasan kajian mempunyai skor tahap kebolehupayaan pejalan kaki yang tinggi, memudahkan pengguna ke sesuatu destinasi dan menjadikan aktiviti berjalan kaki sebagai mod pengangkutan yang lestari. Kesimpulannya, kebolehupayaan pejalan kaki yang baik dapat mengurangkan kesesakan lalu lintas dan meningkatkan aktiviti pelancongan sedia ada.
\end{abstract}

Kata kunci: GIS, indeks, indikator, kebolehupayaan pejalan kaki, pelancongan, pengangkutan

\section{Assessing the walkability in UNESCO's World Heritage Site: A case study in George Town, Penang}

\begin{abstract}
Walkability is one of the sustainable elements which provides many benefits including healthy lifestyle, economic growth and urban planning. In Malaysia, this element is new and limited to advanced metropolitan cities such as Kuala Lumpur, Johor Bahru and George
\end{abstract}


Town. Nowadays, walkability may be used as a sustainable mode in transportation system. The purpose of the study is to measure and evaluate the walkability index of George Town, a World Heritage Site in Penang. The walkability index includes indicators such as land use mix, connectivity index and net retail area index (commercial land). These indicators are usually analysed, evaluated and integrated using the Geographic Information System application to produce the walkability map. The validation is performed through questionnaires and interviews for each specific location to gauge the accucracy of the walkability index map. The finding of this study shows that George Town score high on walkability index, which indicates easier to travel to a destination and walking as the sustainable mode of transport. As a conclusion, a higher walkability index is able to reduce traffic congestion and encourage increases in tourism activity.

Keywords: GIS, index, indicator, walkability, tourism, transportation

\section{Pengenalan}

Kebolehupayaan pejalan kaki atau "walkability" semakin popular di pusat-pusat bandar negara maju seperti Amerika Syarikat, Australia, Kanada dan Eropah namun di Malaysia ia adalah suatu aktiviti yang baru. Aktiviti ini telah menyumbang banyak kebaikan kepada persekitaran bandar, dan yang lebih penting 'mengembalikan bandar' kepada pejalan kaki untuk mengguna dan menikmati persekitarannya termasuk membeli-belah, bersiar-siar dan sebagainya, disamping menyihatkan tubuh badan dan mengurangkan kesan negatif dari pengunaan kenderaan bermotor. Aktiviti berjalan kaki dapat memberikan mannfaat perniagaan dan pendapatan kepada penduduk tempatan bagi mengkomersialkan produk dan perkhidmatan sedia ada. Bagi para pelancong pula, mereka sangat mengemari kawasankawasan yang telah diwartakan sebagai laluan pejalan kaki kerana itulah mod pergerakan utama mereka bagi mengetahui gaya hidup, budaya setempat dan seni binaan tempatan di samping membeli belah.

Sehubungan dengan itu, satu kajian telah dibuat di tapak warisan George Town, Pulau Pinang. Ciri-ciri atau parameter yang membentuk kebolehupayaan pejalan kaki yang dikenalpasti dijadikan bahan asas dalam menilai keadaan dan indeks yang terdapat di tapak kajian. Pengkaji juga melalui kajian pemerhatian telah menghasilkan ciri-ciri reka bentuk bandar dan kualiti alam binaan seperti kegunaan bangunan, senibina bangunan, kesesuaian visual, laluan pejalan kaki, nisbah ruang binaan dan ruang bandar, lalu lintas kenderaan, kemudahan tempat letak dan perilaku pejalan kaki itu sendiri. Satu lagi komponen penting berkaitan "walkable street" adalah persepsi pengguna itu sendiri dan untuk itu satu temuselidik bersemuka telah dibuat di beberapa lokasi terpilih di dalam dan di sekitar tapak kajian. Berdasarkan maklumat yang terkumpul di tapak kajian, satu penganalisaan masalah dan potensi telah dibuat dan akhirnya satu cadangan berbentuk konsep dan skema telah dikemukakan.

Kebolehupayaan pejalan kaki merujuk kepada aktiviti fizikal seperti berjalan atau berbasikal merupakan satu isu atau topik yang dikaji terutama berkaitan di kawasan bandar yang maju. Contohnya, di negara Eropah, Kanada, Amerika Syarikat dan Jepun kajian mengenai kebolehupayaan pejalan kaki dikaitkan dengan kesihatan dan perancangan bandar (Jeff, 2012). Selain itu, Melbourne (Australia), Curitiba (Brazil) dan Singapura menjadikan aktiviti berjalan kaki sebagai satu transformasi sesebuah bandar yang lestari (Jeff, 2012). Dalam bandar lestari interaksi antara keseimbangan sosial, ekonomi dan persekitaran dapat memberikan kehidupan yang baik kerana ia digunakan untuk mengukur tahap kemesraan sesebuah kawasan. Sebuah kejiranan lestari mestilah memperuntukkan ruang yang cukup 
untuk warga komuniti bersenam, beriadah dan berjalan kaki dalam suasana yang selamat dan selesa.

Konsep kebolehupayaan pejalan kaki menyediakan satu prinsip utama terhadap reka bentuk bandar yang baik yang memberikan persepsi masyarakat, mempengaruhi perspektif dan tingkah laku mereka (Jeff, 2012). Kebolehupayaan pejalan kaki ini dapat menghubungkan antara persekitaran dengan masyarakat di sekeliling terutama dalam kawasan kediaman. Kebolehupayaan pejalan kaki biasanya wujud di pusat bandar kerana mempunyai akses kemudahan yang lengkap dan jaringan hubungan yang baik untuk aktiviti berjalan kaki. Hal ini juga melibatkan keselamatan, keselesaan dan faedah individu masingmasing. Keadaan ini penting untuk laluan pejalan kaki yang baik dan bersih iaitu lintasan pejalan kaki, ketinggian dan utiliti asas untuk memenuhi keperluan dan kehendak masyarakat supaya manusia boleh berjalan di kawasan itu dan tidak bimbang terhadap keselamatan mereka ketika mereka sedang berjalan di sepanjang jalan. Cullen (1978) meneroka elemen wawasan siri yang memberi kesan persepsi manusia dan tingkah laku serta membolehkan rangsangan psikologi ketika berjalan. Umumnya, banyak bandar-bandar kontemporari mempunyai kekurangan mengenai aspek ini (Jeff, 2012).

Aktiviti berjalan di bandar seperti percutian, perniagaan, dan sebagainya, merupakan tempat 'walkable' bagi menggalakkan orang ramai untuk sentiasa menggunakan dan menikmati mod pengangkutan dengan berjalan. Bandar 'walkable' tidak hanya menawarkan mod pengangkutan yang cekap dan murah, tetapi meletakkan persekitaran bandar pada skala kelestarian sumber iaitu semula jadi dan ekonomi serta membawa kepada peningkatan interaksi sosial (Jeff, 2012).

Dalam konteks kajian ini, kebolehupayaan pejalan kaki merupakan satu cabang dalam kajian geografi dalam menilai dan mengkaji berkaitan dengan analisis ruangan yang menentukan kadar manusia yang berjalan kaki dengan kawasan yang mudah diakses dengan berjalan dan kawasan manakah di dalam sesebuah bandar khususnya yang paling ramai orang berjalan dengan berbantukan faktor-faktor potensi dan halangan sebagai contohnya seperti jenayah, keselamatan, pencemaran, umur, jantina, prasarana awam, dan kelas masyarakat (Andrews et. al., 2012). Kebolehupayaan pejalan kaki sesebuah kawasan adalah kawasan yang boleh diakses dengan berjalan berdasarkan ukuran bagaimana mesra sesebuah kawasan tersebut untuk aktiviti berjalan. Mesra sesebuah kawasan memberikan manfaat kepada pejalan kaki untuk aktiviti berjalan kaki.

\section{Kajian Literatur}

\section{Konsep kebolehupayaan pejalan kaki}

Aktiviti berjalan merupakan aktiviti rutin dalam kehidupan harian yang mempunyai manfaat dari segi kesihatan, pengangkutan, alam sekitar, ekonomi, kualiti dan keadilan hidup bersosial (Emina, 2006). Dari segi kesihatan, aktiviti berjalan kaki ini dapat mengurangkan risiko penyakit jantung, strok, diabetes dan penyakit kronik yang lain. Aktiviti berjalan kaki ini merupakan aktiviti fizikal dan memerlukan sekurang-kurangnya 30 minit dalam sehari untuk mengekalkan kesihatan yang optimum (Emina, 2006). Manfaat dari segi pengangkutan pula, aktiviti berjalan kaki ini dapat mengurangkan kesesakan lalu lintas, pembaziran masa dan tenaga, masalah pencemaran dan tekanan ketika memandu. Hal ini disebabkan oleh penggunaan mod pengangkutan secara berjalan kaki tidak memerlukan ruang yang besar (Emina, 2006). Selain itu, faedah terhadap persekitaran seperti pencemaran udara dapat diminimumkan. Berdasarkan laporan Agensi Perlindungan Alam Sekitar (Environmental Protection Agency - EPA), pengangkutan tidak mesra alam menyumbangkan 80 peratus 
karbon monoksida dan 55 peratus pembebasan nitrogen oksida di Amerika Syarikat (Emina, 2006). Di samping itu, dari segi manfaat ekonomi pula, aktiviti berjalan kaki merupakan aktiviti yang mampu dilakukan oleh orang ramai dan tidak memerlukan kos yang tinggi berbanding pengangkutan lain. Hal ini dapat memberikan penjimatan dari segi kewangan seperti bayaran tempat letak kereta dan minyak (Jeff, 2012). Kesemua manfaat ini dapat memberikan kepada kualiti hidup yang sihat dan keadilan sosial di sesuatu kawasan khususnya penduduk di bandar. Faktor-faktor yang mempengaruhi aktiviti berjalan termasuk kehadiran dan kualiti laluan pejalan kaki, kaki lima pejalan kaki, lalu lintas dan keadaan jalan, corak penggunaan tanah, pembinaan akses, keselamatan, dan lain-lain. Perkara ini dapat menarik orang ramai terutama pelancong untuk menikmati kemudahan dan hidup berkomuniti di samping menyumbangkan kepada peningkatan kebolehupayaan pejalan kaki (Jeff, 2012). Manfaat aktiviti berjalan kaki ini dapat mewujudkan konsep kelestarian dalam sesebuah bandar.

Aktiviti berjalan kaki adalah satu konsep yang penting dalam reka bentuk bandar yang mampan atau lestari (Ewing \& Cervero, 2001; Frank et al., 2007; Frank et al., 2010; Leslie et al., 2007). Kelestarian dalam kebolehupayaan pejalan kaki ini adalah sesuai dipraktikkan apabila kewujudan persekitaran tersebut begitu selamat, saling berhubungan, akses yang baik dan pilihan mod pengangkutan yang menyenangkan (Abley, 2005). Di samping itu, aktiviti berjalan kaki boleh dinilai pada pelbagai skala. Pada skala tapak, aktiviti berjalan dipengaruhi oleh kualiti laluan, laluan di antara bangunan dan kemudahan yang berkaitan (Jabatan Perancang Bandar dan Desa, 2013). Di peringkat jalan atau kejiranan, ia dipengaruhi oleh kewujudan kaki lima dan lintasan serta keadaan jalan iaitu merujuk kepada kelebaran jalan raya, jumlah trafik dan kelajuan (JPBD, 2013). Di peringkat komuniti ia juga dipengaruhi oleh kebolehcapaian penggunaan tanah, seperti lokasi relatif destinasi biasa dan kualiti sambungan di antara destinasi tersebut (Dobesova \& Krivka, 2012). Kelestarian bandar melalui aktiviti berjalan kaki dapat dilihat melalui bandar-bandar contoh di peringkat global.

Pada peringkat global, bandar yang maju seperti bandar Toronto, bandar Stockholm dan bandar Kirkland merupakan sebahagian bandar yang sesuai dan dilabelkan sebagai kegiatan untuk aktiviti kebolehupayaan pejalan kaki kerana mempunyai rangkaian jalan raya yang selamat, aksesibiliti yang baik untuk ke sesuatu destinasi, variasi mod pilihan pengangkutan dan taraf hidup yang baik (Jeff, 2012). Hal ini dibuktikan melalui keunikan ciri kebolehupayaan pejalan kaki iaitu aksesibiliti, keselesaan, tarikan, jalan raya yang selamat, dan keselamatan individu. Bandar-bandar tersebut juga dijadikan kawasan tarikan pelancong dunia untuk menikmati keindahan dan keistimewaan yang terdapat di situ. Bandar-bandar yang disenaraikan tersebut mempunyai indeks kebolehupayaan pejalan kaki yang tinggi dan sememangnya mempunyai kriteria bandar yang sesuai untuk aktiviti berjalan kaki (walkable city) (Jeff, 2012). Indeks kebolehupayaan pejalan kaki memang berguna dalam peringkat perancangan bandar. Nilai indeks kebolehupayaan pejalan kaki yang tinggi memberi erti penyusunan dalam kawasan bandar menyokong aktiviti fizikal manusia. Manakala, indeks kebolehupayaan pejalan kaki yang rendah membawa maksud manusia sangat rapat dengan penggunaan kereta setiap hari sehingga meminimumkan aktiviti fizikal dalam kawasan tersebut. Kini, perancangan bandar menggunakan format digital dan Sistem Maklumat Geografi (GIS) berperanan dalam mencipta dan mengekalkan perancangan tersebut. Kemunculan GIS dapat memberikan keputusan yang terbaik dalam penghasilan nilai kebolehupayaan pejalan kaki di kawasan yang ingin dikaji. Secara tidak langsung penggunaan GIS ini dapat memberikan satu output baharu dalam proses penambahbaikan terutama untuk menggalakkan aktiviti berjalan kaki. 


\section{Indikator pengukuran kebolehupayaan pejalan kaki}

Kebolehupayaan pejalan kaki dapat diukur dengan pembolehubah atau indikator tertentu yang telah digunakan oleh penyelidik terdahulu. Antara indikator yang sering digunapakai oleh penyelidik bagi integrasi menilai kebolehupayaan pejalan kaki adalah kepadatan penduduk, kepadatan perhubungan, campuran guna tanah, dan nisbah perniagaan. Kajian yang dijalankan oleh Mayne et al. (2013) menilai indeks kebolehupayaan pejalan kaki dengan empat indikator di Sydney, Australia iaitu menghubungkaitkan antara status pendapatan dengan indeks kebolehupayaan pejalan kaki (sangat tinggi, tinggi, sederhana, rendah dan sangat rendah). Secara keseluruhan, kajian tersebut mendapati bahawa bandar Sydney merupakan kawasan yang mempunyai kebolehupayaan pejalan kaki yang tinggi dan hal ini telah memberi impak positif di persekitaran bandar tersebut. Kaedah indikator ini juga telah dijalankan oleh Lachapelle et al. (2009) dan Frank et al. (2010) dengan mengambil kira keempat-empat indikator bagi menentukan indeks kebolehupayaan pejalan kaki. Frank mengubahsuai keadaan nisbah perniagaan kepada kepada komersial dan menggabungkan lagi tiga indikator yang lain. Kajian Frank et al. (2010) merupakan pendekatan yang terperinci dari segi kategori campuran guna tanah.

\section{Hubungan kebolehupayaan pejalan kaki dengan tapak warisan}

Lokasi pemetaan tapak warisan yang mempunyai nilai yang tinggi dan indeks kebolehupayaan pejalan kaki di kawasan tersebut. Hal ini disebabkan keunikan dari segi bangunan, susun atur kedai, jalan raya, kemudahan awam dan kebolehtersampaian ke tempat yang ingin dituju telah memberikan keselesaan kepada penduduk tempatan dan orang luar terutama pelancong. Takrifan pemetaan bersejarah merujuk kepada tapak warisan yang telah dikhususkan dan diiktiraf sama ada di peringkat global mahupun peringkat lokal. Kajian yang dijalankan oleh membuktikan bahawa kawasan tapak warisan lebih cenderung kepada peningkatan pejalan kaki. Kajian Khairi et al. (2017) mengenai sejarah tapak warisan dapat di lihat di bandar Tripoli, Libya yang memperkenalkan tiga konsep iaitu kepadatan, kepelbagaian dan kemudahan destinasi. Di samping itu, kajian beliau juga melihat kepada aspek keselamatan dan kawalan. Hasil kajian tersebut mendapati kawasan tapak warisan memberi satu platform dari segi kebolehupayaan pejalan kaki dan seterusnya memperkenalkan budaya kelestarian alam di dalam kawasan bandar. Manakala, kajian yang dijalankan oleh Zainol et al. (2016) melihat kebolehupayaan pejalan kaki di sekitar tapak warisan dunia George Town Pulau Pinang berdasarkan kepada keadaan fizikal yang terlibat termasuk laluan zebra, laluan pejalan kaki, penanda, keselamatan, aliran trafik dan kemudahan. Hasil daripada penyelidikan beliau mendapati George Town mempunyai tahap kepuasan yang rendah dan tahap ketidakpuasan yang tinggi kepada garisan zebra yang sedia ada. Tanpa keadaan fizikal yang sempurna, tahap kebolehupayaan pejalan kaki tidak dapat ditingkatkan walaupun walkscore yang diakses adalah sekitar 80 peratus dan ke atas. Pandangan ini selari dengan kajian yang dijalankan oleh Tulin Vulan Arslan et al. (2018) yang menilai faktor kebolehupayaan pejalan kaki utama di sekitar kawasan bandar bersejarah di Bursa Turki. Hasil penemuan tersebut, faktor aksesibiliti, keselesaan, keselamatan trafik, kawalan jenayah, dan sistem perhubungan merupakan faktor terpenting berbanding faktor umum seperti politik, sosial dan ekonomi. 


\section{Kawasan dan metod kajian}

Bandaraya George Town merupakan kawasan kajian yang dipilih kerana mempunyai ciri-ciri utama iaitu pembandaran. Bandar George Town yang terletak di wilayah utara Semenanjung Malaysia iaitu pada longitud $100^{\circ} 27^{\prime} 22.4568^{\prime \prime}$ Timur dan latitud $5^{\circ}$ 17' 6.5508" Utara (Jabatan Perangkaan Malaysia, 2015). Bandar Warisan Dunia George Town juga dikenali sebagai ibu negeri bagi negeri Pulau Pinang (JPBD Pulau Pinang, 2009). Kedudukan bandaraya George Town adalah terletak di dalam daerah Timur Laut, Pulau Pinang (Rajah 1). Pelbagai aktiviti dijalankan di kawasan bandaraya ini sehingga menjadi tumpuan penduduk tempatan mahupun penduduk luar terutama pelancong. Walau bagaimanapun kajian ini melihat aspek yang ingin dikaji di dalam kawasan zon teras dan zon penampan tapak warisan George Town seperti yang ditunjukkan dalam Rajah 2. Bandaraya George Town merupakan salah satu tapak warisan dunia yang diiktiraf oleh UNESCO selain daripada bandar dunia lain seperti Venice, Borobudur, Angkor Wat dan Hoi An.

Pulau Pinang merupakan antara tiga destinasi pelancongan yang popular di Malaysia yang mempunyai keunikan dari segi sejarah warisan, kebudayaan dan keagamaan. George Town juga telah dijadikan pusat perniagaan dan zon pentadbiran Pulau Pinang yang menyokong pertumbuhan ekonomi dan kepesatan bandar tersebut. Dari segi kependudukan pula, George Town meliputi 30 peratus daripada keseluruhan penduduk di Pulau Pinang iaitu 1,773,442 orang (Jabatan Perangkaan Malaysia, 2015). Oleh hal demikian, kajian ini telah diambil kawasan utama tapak warisan George Town iaitu zon teras (109.38 hektar) dan zon penampan (150.04). Tapak warisan George Town mempunyai keluasan 259.42 hektar dan merangkumi jumlah bilangan bangunan sebanyak 4,665 buah bangunan.

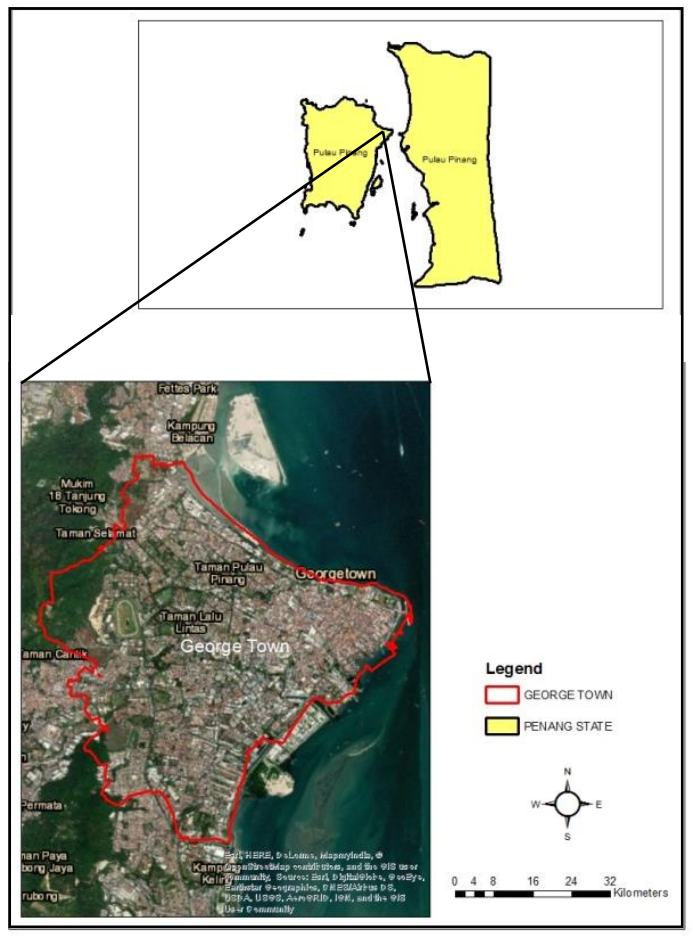

Rajah 1. Bandar Warisan Dunia George Town, Pulau Pinang 


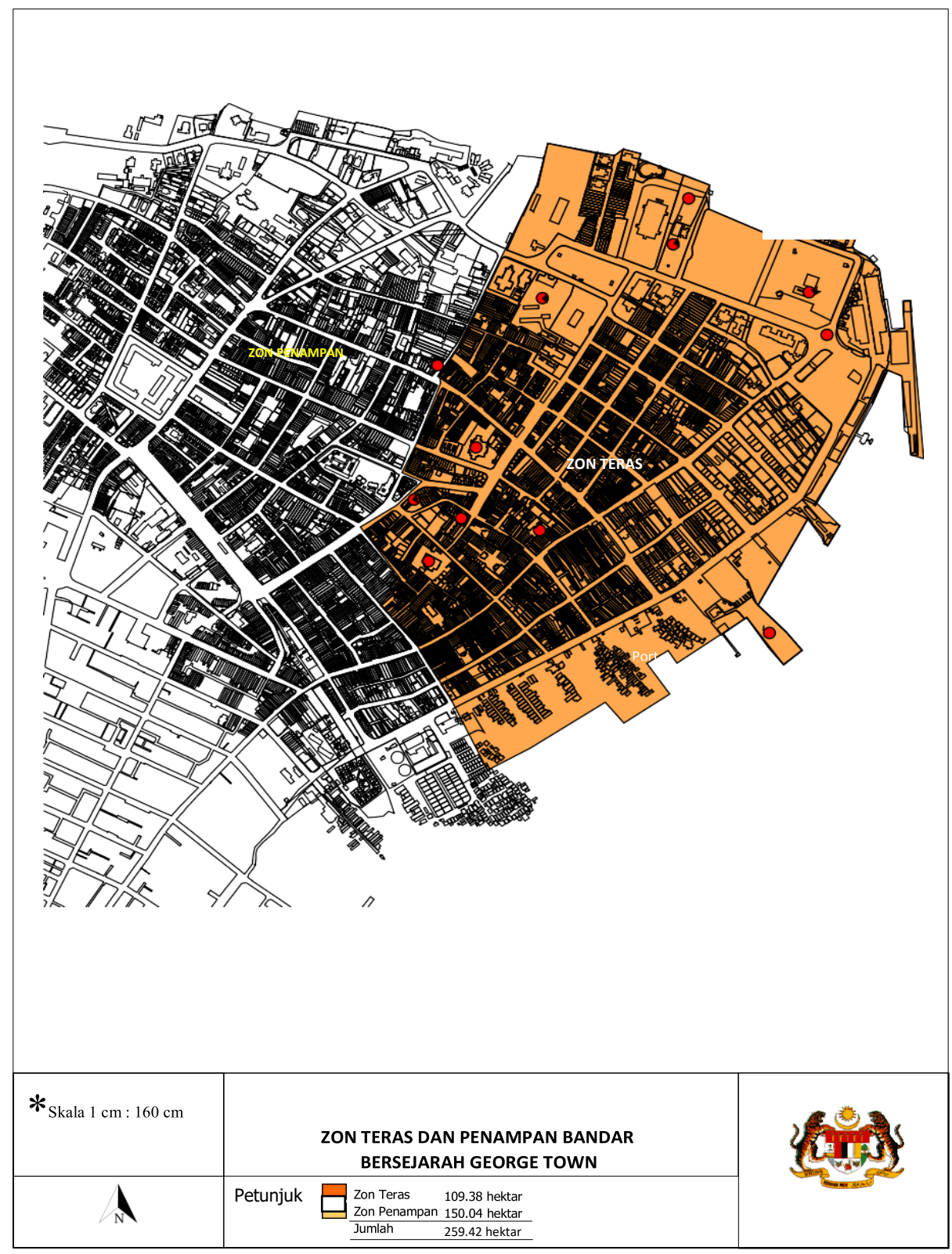

Sumber: Jabatan Perancang Bandar dan Desa Pulau Pinang, 2013

Rajah 2. Kawasan Zon Warisan Dunia George Town Pulau Pinang

Pemetaan menggunakan aplikasi GIS menggabungkan data ruangan dan data bukan ruangan kawasan kajian yang merangkumi koordinat pejalan kaki yang dikenalpasti, data guna tanah, data jalan yang digunakan untuk analisis. Data bukan ruangan diperoleh dengan menjalankan kaedah temu bual kepada responden untuk melengkapkan hasil keputusan analisis yang dilakukan. Data format ruangan dilakukan dengan menggunakan langkahlangkah pendigitan dalam ArcMaps 10.1 manakala data-data mentah seperti koordinat dibangunkan menggunakan perisian Excel sebelum dipindahkan ke dalam ArcMaps 10.1 kerana format data dalam bentuk berkenaan lebih mudah dilakukan apabila dimasukkan ke dalam ArcMaps 10.1. Kaedah yang digunakan dalam kajian ini adalah menggunakan pengiraan indeks kebolehupayaan pejalan kaki yang berfokus kepada campuran guna tanah, perhubungan (jalan raya), nisbah bersih perniagaan, faktor keselamatan dan kepadatan penduduk yang boleh mempengaruhi seseorang untuk melakukan aktiviti berjalan kaki di 
kawasan kajian. Walau bagaimanapun, kajian hanya menilai tiga kaedah iaitu campuran guna tanah, perhubungan (jalan raya) dan nisbah perniagaan yang dianalisis menggunakan perisian ArcMaps.

\section{Campuran guna tanah}

Kaedah indeks entropi atau indeks Shanon diaplikasikan dan digunakan bagi menggambarkan persekitaran guna tanah yang pelbagai. Kaedah ini menghuraikan dan memberi kesan kepada kebolehupayaan pejalan kaki sama ada positif ataupun negatif. Keputusan indeks entropi ini dapat memberikan dua keadaan iaitu jika tahap pertindihan rendah (indeks entropi rapat kepada nilai 0, homogen) menghasilkan keputusan kebolehupayaan pejalan kaki secara positif kerana mempunyai ciri-ciri kepelbagaian guna tanah. Manakala jika tahap pertindihan tinggi (indeks entropi rapat kepada nilai 1, heterogen) menghasilkan keputusan kebolehupayaan pejalan kaki secara negatif. Formula dalam pengiraan indikator ini seperti rumus 1 berikut:

$$
\text { Indeks entropi }=-\frac{\sum k(P k \ln P k)}{\ln N}
$$

iaitu

$\mathrm{k}=$ jenis guna tanah

$\mathrm{P}=$ jumlah guna tanah

$\ln =$ pembolehubah malar

$\mathrm{N}=$ bilangan bagi kategori tanah yang disediakan

\section{Perhubungan (jalan raya)}

Indeks kebolehupayaan pejalan kaki mengambil kira indikator perhubungan terutama jalan raya yang sesuai (Berrigan et al., 2010). Dalam kajian ini, data jalan diperlukan bagi menggambarkan data vektor untuk dianalisis sama ada bilangan persimpangan yang ada (tiga atau lebih) bagi menyokong aktiviti berjalan kaki di kawasan kajian (Leslie et al., 2007). Pemilihan persimpangan dibuat secara manual dan ArcGIS 10.1 digunakan sebagai analisis rangkaian. Dalam pemilihan ini, faktor jarak digunakan iaitu antara lingkungan 15 meter (Frank et al., 2010; Dobesova \& Krivka, 2012). Pengiraan indikator ini dapat ditunjukkan seperti pada rumus 2 atau rumus 3 .

$$
\text { Perhubungan }=\frac{\text { Bilangan persimpangan }}{\text { Keluasan } \text { kawasankm }^{2} \text { ) }}
$$

Atau

$$
\text { Perhubungan }=\frac{\text { Bilangan persimpangan } 3 \text { atau lebih simpang) }}{\text { Jumlah persimpangan }}
$$

Selain itu, pengiraan indeks bagi perhubungan dapat dijalankan berdasarkan rumus indeks gamma seperti rumus 4 .

Indeks Gamma $=\frac{\text { Bilangan sebenar link }}{3 *(\text { bilangan nod }-2)}$ 


\section{Kepadatan komersial}

Kepadatan komersial digunakan bagi mengukur kebolehupayaan pejalan kaki dengan melihat jumlah keluasan kawasan pembangunan guna tanah komersial yang berfokus kepada tanah perniagaan di tapak warisan George Town. Pengiraan jumlah kawasan perniagaan mempunyai hubungan dengan jumlah bilangan tanah yang wujud bagi kegunaan perniagaan (Leslie et al., 2007). Persamaan dalam rumus 5 dapat digunakan bagi menerangkan nisbah tersebut.

$N B K P=\frac{N K K P}{J K}$

di mana:

$\mathrm{NBKP}=$ nisbah bersih kawasan perniagaan

$\mathrm{NKKP}=$ nisbah kasar kawasan perniagaan

$\mathrm{JK}=$ Jumlah kawasan

Keluasan bersih perniagaan (NBKP) bersamaan dengan keluasan perniagaan kasar (NKKP) dibahagikan kepada jumlah kawasan perniagaan (Leslie et al., 2007).

Akhir sekali, setelah memperoleh indeks kebolehupayaan pejalan kaki bagi setiap indikator, maka nilai tersebut digabungkan. Persamaan pada rumus 6 dapat menunjukkan dan digunakan sebagai platform pengiraan keseluruhan indeks kebolehupayaan pejalan kaki di kawasan kajian. Rumus ini berdasarkan teori Manaugh \& El Geneidy (2011).

$\begin{aligned} I K P K=I E & +P \\ & +N B K P\end{aligned}$

di mana:

IKPK iaitu indeks kebolehupayaan pejalan kaki

IE iaitu indeks entropi

$P$ iaitu Perhubungan

NBKP iaitu nisbah bersih keluasan perniagaan

\section{Hasil dan perbincangan kajian}

Keputusan analisis yang dijalankan menghasilkan imej pemetaan indeks kebolehupayaan pejalan kaki di tapak warisan George Town Pulau Pinang. Penghasilan peta ini mengambil kira faktor gabungan pengiraan indeks kebolehupayaan pejalan kaki iaitu perhubungan jalan raya, indeks entropi (campuran gutanah) dan nisbah bersih perniagaan (tanah komersial).

Rajah 3, 4 dan 5 yang dipaparkan merupakan hasil faktor yang diambil dalam menilai kebolehupayaan pejalan kaki. Rajah 6 menunjukkan hasil tindanan secara puratanya menunjukkan tahap indeks yang baik kerana majoriti kawasan George Town terutama di kawasan tapak warisan adalah berpotensi untuk melakukan aktiviti berjalan kaki. Hal ini disebabkan oleh faktor penarik seperti kemudahan awam, talian perhubungan, perniagaan komersial, dan keadaan persekitaran yang disediakan pada tahap yang baik. Penilaian indeks kebolehupayaan pejalan kaki ini memberikan satu impak yang positif terhadap mod pengangkutan di kawasan kajian ini. Di samping itu, keadaan persekitaran seperti laluan pejalan kaki untuk perhubungan dan faktor keselamatan diambil kira dalam menilai kebolehupayaan pejalan kaki. Kadar populasi penduduk yang terdapat di kawasan kajian 
sama ada penduduk tempatan atau pelancong meningkatkan lagi kadar manusia untuk melakukan aktiviti fizikal berjalan kaki.

Pada akhir analisis ini, nilai indeks kebolehupayaan pejalan kaki ini bagi kesemua faktor digabungkan untuk melihat keseluruhan indeks dan peratusan potensi pergerakan manusia menjalani aktiviti berjalan kaki di tapak warisan George Town khususnya tapak warisan.

Perbincangan ini berdasarkan ulasan literatur yang lepas, kepelbagaian dalam kajian ini merujuk kepada guna tanah yang menjadi komponen penting dalam membuat pengukuran kebolehupayaan pejalan kaki di kawasan kajian (Brennan Ramirez et al., 2006; Tucker et al., 2009; Brownson et al., 2009; Feng et al., 2010). Hasil daripada analisis yang dijalankan menunjukkan bahawa kawasan kajian mempunyai kepelbagaian dari segi guna tanah dan pelbagai aktiviti yang dapat menarik indeks entropi ini seperti di dalam rajah 5 .

Selain itu, peta indeks perhubungan yang dihasilkan pada rajah 4 menunjukkan taburan rangkaian jalan di kawasan kajian. Hasil kajian mendapati bahawa terdapat perhubungan yang baik dan sesuai bagi menilai indeks kebolehupayaan pejalan kaki. Sehubungan dengan itu, pengiraan indeks bagi tanah komersial pada rajah 3 telah menunjukkan taburan berpusat di tengah bandar George Town.

Walau bagaimanapun, kajian ini hanya mengambil kira tiga faktor atau indikator iaitu, indeks entropi, indeks nisbah perniagaan dan perhubungan bagi menghasilkan nilai kebolehupayaan pejalan kaki di kawasan tersebut. Ketiga-tiga indikator ini menjadi satu gambaran awal bagi menentukan indeks kebolehupayaan pejalan kaki berbanding menggunakan kesemua model yang sedia ada.

Secara kesimpulannya, penilaian indeks kebolehupayaan pejalan kaki di tapak warisan adalah tinggi iaitu 82.53 peratus dan ia berpotensi sebagai kawasan utama bagi pejalan kaki. Aktiviti berjalan kaki ini dijadikan satu medium mod pengangkutan utama untuk ke sesuatu destinasi yang dapat menjimatkan masa dan ruang. Masa dan ruang dapat diminimumkan melalui aktiviti berjalan kaki kerana di kawasan kajian merupakan kawasan tumpuan orang ramai dan kesesakan lalu lintas yang amat tinggi. Penekanan diberikan kepada tiga faktor utama iaitu, campuran guna tanah, perhubungan, dan taburan perniagaan sedia ada di kawasan kajian ini. Selain daripada tiga faktor, faktor penduduk dan keselamatan merupakan faktor tambahan yang dapat mempengaruhi nilai indeks kebolehupayaan pejalan kaki. Perkara ini dijadikan sebagai alternatif bagi menyokong nilai yang diperoleh dan seterusnya dapatan kajian ini dikukuhkan dengan penilaian walkscore dan temubual yang dijalankan. 


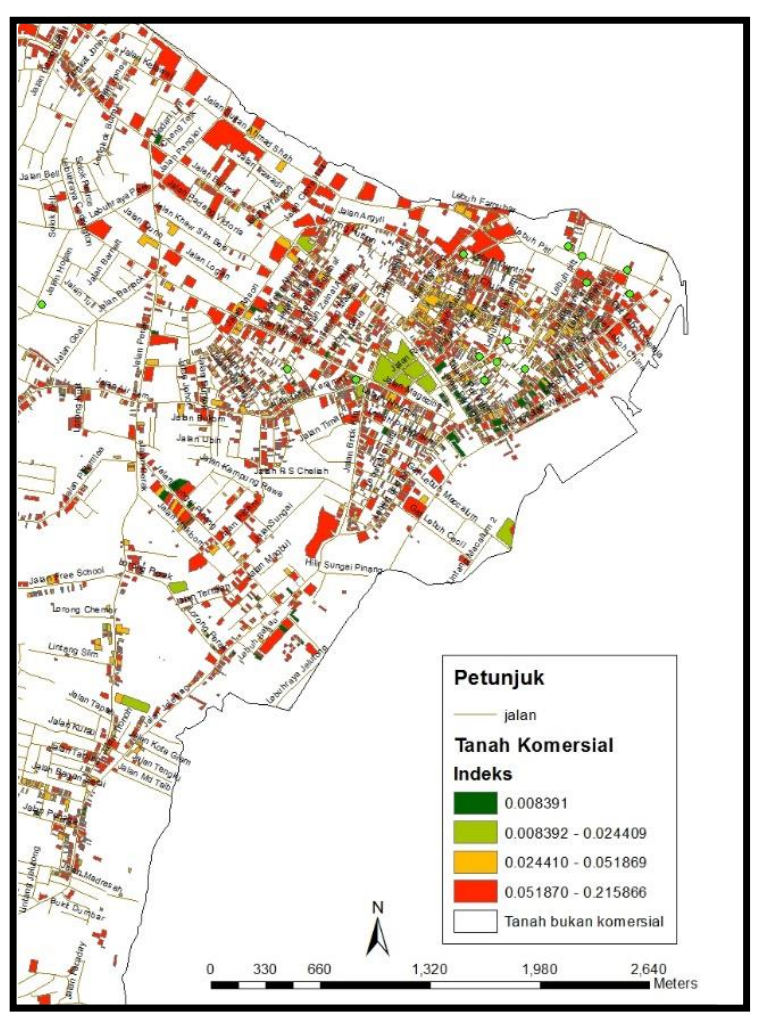

Rajah 3. Indeks tanah komersial

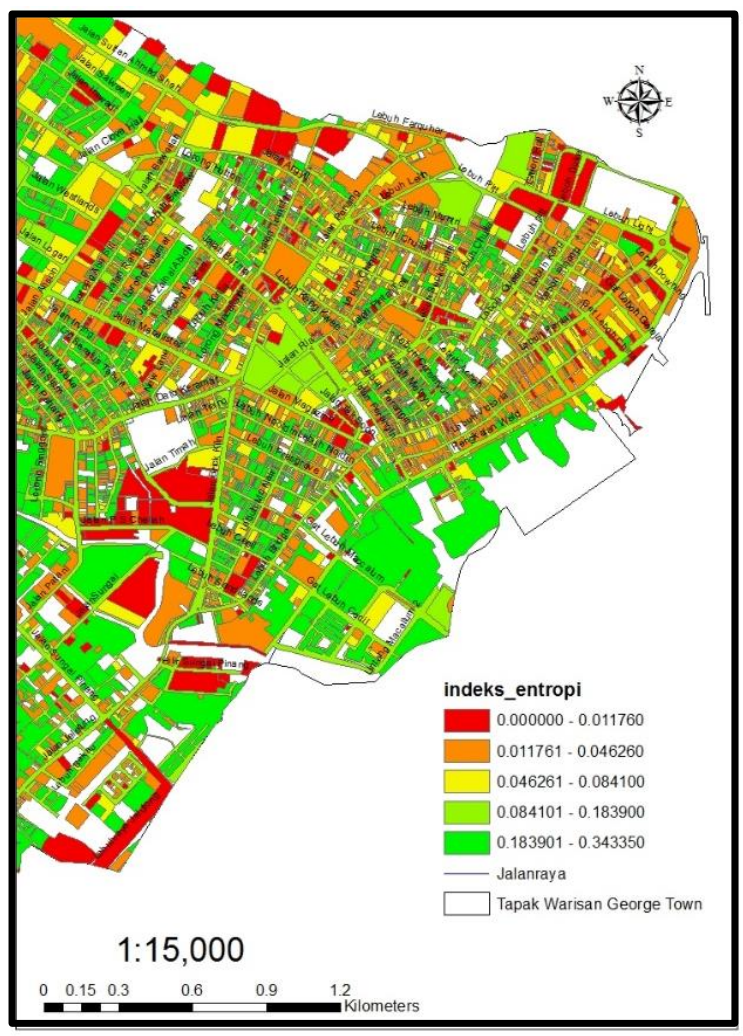

Rajah 5. Indeks entropi guna tanah

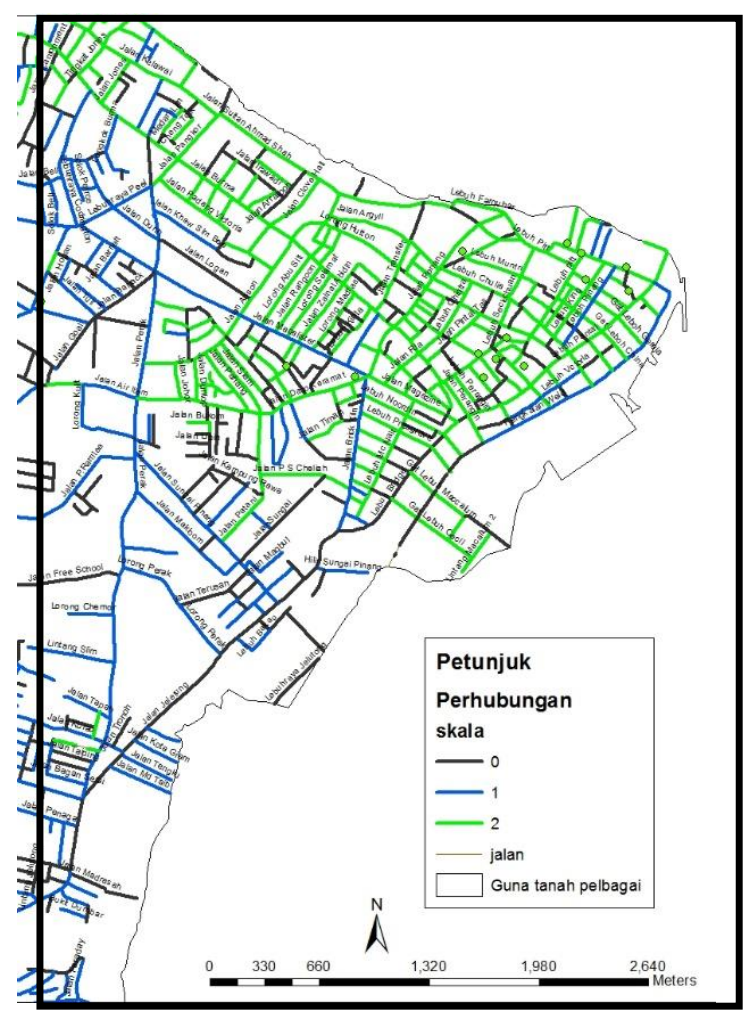

Rajah 4. Indeks perhubungan

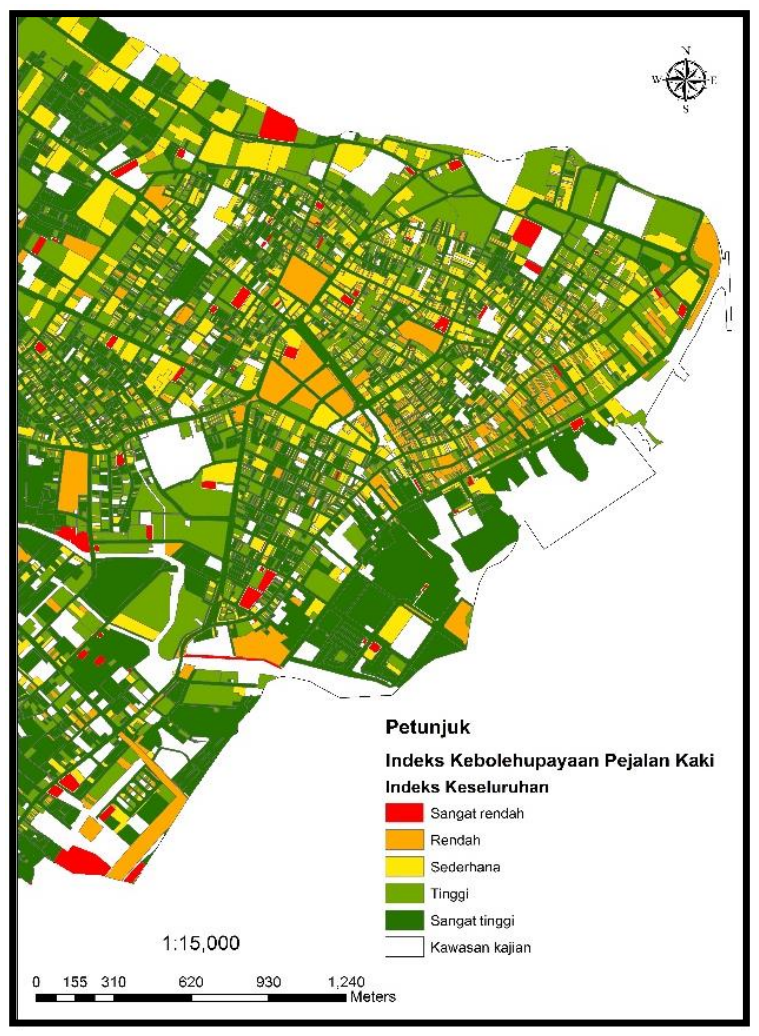

Rajah 6. Indeks kebolehupayaan pejalan kaki 


\section{Perbincangan dan analisis pengesahan indeks kebolehupayaan pejalan kaki}

Penyelidik terdahulu telah menjalankan kajian ini dengan menggunakan kaedah kuantitatif iaitu mengemukakan soal selidik berstruktur kepada responden bagi mengenalpasti pandangan dan persepsi kebolehupayaan pejalan kaki di sesuatu kawasan. Berdasarkan kajian dan pemerhatian yang dijalankan, faktor fizikal dan kebolehtersampaian atau akses dari satu tempat ke satu tempat mempengaruhi peningkatan pejalan kaki. Di samping itu, keadaan fizikal kawasan yang sangat rapat boleh menggalakkan tingkah laku pejalan kaki dan seterusnya meningkatkan kelestarian alam. Walau bagaimanapun, kaedah kualitatif berdasarkan kepada temubual daripada responden telah diambil kira bagi melihat potensi kebolehupayaan pejalan kaki. Kaedah kualitatif ini bertujuan untuk mengesahkan ramalan terhadap kebolehupayaan pejalan kaki. Analisis pengesahan indeks kebolehupayaan pejalan kaki melalui kaedah temubual kepada responden secara rawak dijalankan dengan mengambil kira faktor lokasi atau destinasi ingin dituju, laluan pejalan kaki sedia ada dan keselamatan.

Berdasarkan hasil yang dijalankan, kawasan kajian merupakan lokasi yang mempunyai kebolehupayaan tinggi untuk aktiviti berjalan kaki dan berpotensi dalam pembangunan kesihatan yang lestari. Oleh itu, kaedah pengesahan berdasarkan teknik temu bual mengikut borang soal selidik yang diedarkan. Bilangan sampel responden adalah seramai 10 orang yang terdiri daripada orang awam termasuk warga tempatan dan pelancong. Pemilihan responden ini berdasarkan kajian fenomena oleh pandangan Cresswel (1998) iaitu antara 5 hingga 25 orang dan Morse (1994) mencadangkan sekurang-kurangnya 6 orang responden. Secara keseluruhan, kesemua soalan yang dikemukakan oleh penyelidik kepada responden adalah baik dan menepati kehendak kajian. Kaedah ini juga adalah untuk mengenalpasti tingkahlaku manusia khususnya responden dalam memilih mod pengangkutan secara mesra alam. Melalui kaedah temu bual ini, maklumat berkaitan yang diperlukan mengenai kebolehupayaan pejalan kaki di kawasan kajian dapat diketengahkan. Dalam temu bual yang dijalankan, persoalan tentang lokasi responden adalah penting untuk menilai tahap kebolehupayaan untuk berjalan kaki dari satu destinasi ke destinasi yang lain termasuk tempat menarik dan akses kemudahan yang diperlukan. Jalan Penang, Jalan Ria, Jalan Pasar, Lebuh Melayu, Lebuh Armenian, Lebuh Chulia, Lebuh Pantai dan kawasan sekitar padang Kota Lama merupakan kawasan yang mempunyai tahap kebolehupayaan pejalan kaki yang tinggi kerana responden yang ditemubual melakukan aktiviti berjalan kaki di sekitar kawasan tersebut.

Temu bual ini dilanjutkan dengan tujuan responden datang ke tapak warisan George Town sama ada bekerja, pelancong, membeli belah ataupun melawat tapak sejarah UNESCO. Daripada hasil temu bual yang dijalankan mendapati aktiviti berjalan kaki adalah penting untuk ke sesuatu tempat kerana kawasan kajian ini merupakan mempunyai kenderaan yang banyak sehingga berlaku kesesakan lalu lintas. Kebolehupayaan pejalan kaki dapat dilihat mengikut waktu-waktu tertentu terutama pada hari bercuti termasuk sabtu dan ahad. Pergerakan pejalan kaki adalah tinggi pada waktu tersebut untuk ke tempat-tempat sejarah di tapak warisan. Hal ini berikutan keadaan senibina bangunan yang lama dan sempit untuk akses kemudahan meletak kenderaan oleh orang ramai menarik minat untuk berjalan kaki. Bagi responden pelancong asing gemar untuk berjalan kaki dan berbasikal untuk ke destinasi utama yang menarik kerana mereka suka aktiviti mengambil foto. Bagi responden yang telah lama tinggal di kawasan George Town berpotensi untuk menggunakan kemudahan pengangkutan awam seperti bas dan teksi untuk ke sesuatu tempat. Selain itu, terdapat responden menggunakan kenderaan sendiri seperti motor dan kereta sebagai mod pengangkutan di dalam kawasan tapak warisan. Walau bagaimanapun, pernyataan responden terhadap penggunaan pengangkutan sendiri adalah dari segi pembaziran masa dan kos seperti minyak dan wang ringgit iaitu kupon meletak kenderaan telah merumitkan responden untuk 
ke sesuatu destinasi. Keadaan ini memaksa responden memilih untuk bergerak dengan berjalan kaki di kawasan yang berdekatan.

Di samping itu, perbandingan masa iaitu pada waktu siang dan malam dapat dilihat serta dinilai kebolehupayaan pejalan kaki di tapak warisan. Secara relatifnya, waktu siang terutama musim cuti adalah lebih ramai untuk berjalan kaki berbanding waktu malam kerana kemudahan yang disediakan adalah lebih panjang dan lama. Walau bagaimanapun waktu malam kebanyakan orang berjalan kaki untuk ke restoran, hiburan dan lain-lain. Tambahan lagi, waktu malam segala operasi perniagaan telahpun ditutup dan aktiviti berjalan kaki adalah kurang.

Dari segi faktor keselamatan pula, responden menyatakan di tapak warisan merupakan kawasan yang selamat dan kurangnya berlaku jenayah tetapi kesesakan lalu lintas semakin hari semakin bertambah. Hal ini disebabkan oleh penggunaan kenderaan yang melampau oleh pengguna jalan raya. Walau bagaimanapun, akses bagi kemudahan pejalan kaki yang sedia ada dapat memberikan keselamatan kepada pengguna jalan kaki dan basikal. Keadaan ini memberikan keselesaan kepada mereka yang berjalan kaki. Bagi pejalan kaki yang melakukan aktiviti berjalan kaki ke destinasi yang ingin dituju, perlu mengambil langkah dengan berjalan di tempat atau jalanraya yang mempunyai tumpuan orang ramai supaya kelihatan. Selain itu, balai polis sedia ada dan berdekatan memudahkan lagi responden serta orang ramai terhadap keselamatan diri. Pandangan tentang faktor keselamatan ini selari dengan idea Bradshaw (1993) yang menyatakan kawasan yang mempunyai banyak bangunan dan tumpuan orang ramai menjamin keselamatan sesorang individu sama ada berjalan waktu siang ataupun malam.

Dari segi penggunaan jarak perjalanan menggunakan mod pengangkutan berjalan kaki, kebanyakan responden yang ditemu bual berjalan sekitar 0.5 kilometer sehingga 5 kilometer di tapak warisan George Town. Hal ini kerana bangunan dan tempat-tempat di kawasan tersebut adalah berdekatan antara satu sama lain dan tidak memerlukan jarak yang jauh. Perkara ini memudahkan responden bergerak. Jadi, aktiviti berjalan kaki merupakan satu metod yang digunakan dalam pembangunan dan perancangan bandar kerana ia melambangkan satu identiti yang unik dan mesra alam. Daripada hasil temu bual yang dijalankan, mendapati responden lebih berfokus kepada faktor perhubungan, kedekatan, kemudahan awam bagi pejalan kaki dan keselamatan dalam menggalakkan orang ramai untuk berjalan kaki di kawasan kajian ini. Kesemua faktor ini memberi pemberat kepada penilaian kebolehupayaan pejalan kaki dan tingkahlaku manusia dalam memilih mod pengangkutan secara sihat. Secara kesimpulannya dapat dijelaskan, pandangan responden terhadap pengetahuan kebolehupayaan pejalan kaki di sekitar kajian adalah tinggi dan secara tidak langsung dapat memberikan manfaat kepada kehidupan yang lestari dan mesra alam.

\section{Kesimpulan}

Penghasilan peta kebolehupayaan pejalan kaki yang berdasarkan analisis GIS ini dapat memberikan keputusan yang boleh digunapakai dalam mengidentifikasikan kawasan dan laluan yang paling banyak aktiviti berjalan dan sebaliknya di kawasan tapak warisan George Town Pulau Pinang. Secara keseluruhannya, Bandaraya George Town merupakan kawasan yang boleh kita simpulkan sebuah kawasan yang paling banyak berlakunya aktiviti berjalan atau kawasan yang paling "walkable". Namun begitu, kawasan tapak warisan George Town adalah merupakan kawasan yang mempunyai tahap kebolehupayaan pejalan kaki yang tinggi jika berdasarkan kepada peta akhir yang telah dihasilkan. Kajian ini merupakan satu kajian visualisasi untuk menggambarkan kepada senario kebolehupayaan pejalan kaki di dalam kawasan tapak warisan ini. Hasil analisis kajian ini boleh digunakan sebagai output 
tambahbaik untuk kajian pada masa hadapan ataupun data yang telah dibahagikan akan digunakan sebagai pangkalan data untuk mengetahui keadaan atau kondisi kawasan bandar yang sesuai untuk menjalankan aktiviti berjalan yang membawa kepada kebolehupayaan pejalan kaki sesuatu kawasan dalam usaha pihak kerajaan tempatan untuk membaikpulih kawasan yang kurang menjadi tumpuan orang ramai untuk melakukan aktiviti berjalan kaki sebagai mod pengangkutan yang lestari dan sihat.

\section{Penghargaan}

Terima kasih kepada Kementerian Pendidikan Malaysia (KPM) kerana telah membiaya sebahagian penyelidikan ini menerusi dana Skim Geran Penyelidikan Fundamental (FRGS no. 203/PHUMANITI/6711709).

\section{Rujukan}

Abley, S. (2005). Walkability Scoping Paper. Abley Transportation Consultants, Christchurch New Zealand.

Andrews, G.J., Hall, E., Evans, B., Colls, R. (2012). Moving beyond walkability: on the potential of health geography. Journal of Social Science and Medicine, 75(11), 19251932.

Berrigan, D., Pickle, L.W., and Dill, J., (2010). Associations between street connectivity and active transportation: International Journal of Health Geographics, 9(1), 20. https://doi.org/10.1186/1476-072X-9-20

Bradshaw, C. (1993). Creating and using a rating system for neighborhood walkability: Towards an agenda for local heroes. In Proceedings of the 14th International Pedestrian Conference, Boulder, CO, USA, 1 October 1993.

Brennan Ramirez, L.K., Hoehner, C.M., Brownson, R.C., Cook, R., Orleans, C.T., Hollander, M., Barker, D.C., Bors, P., Ewing, R., Killingsworth, R., Petersmarck, K., Schmid, T., Wilkinson, W., (2006). Indicators of activity-friendly communities: an evidence-based consensus process. Am J Prev Med 31, 515-524.

Brownson, R.C., Hoehner, C.M., Day, K., Forsyth, A., \& Sallis, J.F. (2009). Measuring the built environment for physical activity: state of the science. American journal of preventive medicine, $36(4 \quad$ Suppl), $\quad$ S99-123.e12. https://doi.org/10.1016/j.amepre.2009.01.005

Creswell, J.W. (1998). Qualitative inquiry and research design: Choosing among five traditions. Thousand Oaks, CA: Sage Publications.

Cullen, I. (1978). The treatment of time in the explanation of spatial behavior. In T. Carlstein, D. Parkes \& N. Thrift (Eds.). Human activity and time geography, (pp. 27-38). New York, Halstead Press.

Dobesova, Z., \& Krivka, T. (2012). Walkability index in the urban planning: A case study in Olomouc City. In J. Burian (Ed.), Advances in Spatial Planning (pp. 179-196). IntechOpen, DOI: 10.5772/36587. Retrieved from: https://www.intechopen.com/books/ advances-in-spatial-planning/walkability-index-in-the-urban-planning-a-case-study-inolomouc-city

Emina Sendich. (2006). Planning and Urban Design Standards: American Planning Association. Canada, John Wiley \& Sons. Inc.

Ewing, R., \& Cervero R. (2001). Travel and the built environment: A synthesis. Transportation Research Record, 1780, 87-114. 
Feng, J., Glass, T.A., Curriero, F.C., Stewart, W.F., Schwartz, B.S., (2010). The built environment and obesity: a systematic review of the epidemiologic evidence. Health Place, 16, 175-190.

Frank, L.D., Sallis, J.F., Saelens, B.E., Leary, L., Cain, K., Conway, T.L., Hess, P.M., (2010). The development of a walkability index: application to the Neighborhood Quality of Life Study. British Journal of Sports Medicine, 44(13), 924-33. http://dx.doi.org/10.1136/ bjsm.2009.058701.

Frank, L.D., Saelens, B.E., Powell, K.E., \& Chapman, J.E. (2007). Stepping towards causation: do built environments or neighborhood and travel preferences explain physical activity, driving, and obesity? Social Science \& Medicine, 65(9), 1898-1914.

Jabatan Perancangan Bandar dan Desa Semenanjung Malaysia. (2009). Profil Bandar Pulau Pinang. Malaysia, Kementerian Perumahan dan Kerajaan Tempatan.

Jabatan Perancangan Bandar dan Desa Semenanjung Malaysia. (2013). Panduan Pelaksanaan Inisiatif Pembangunan Kejiranan Hijau: Penyediaan laluan pejalan kaki. Malaysia, Kementerian Kesejahteraan Bandar, Perumahan dan Kerajaan Tempatan.

Jabatan Perangkaan Malaysia. (2015). Buletin Perangkaan Sosial: Malaysia 2015. Malaysia, Jabatan Perdana Menteri.

Jeff Speck. (2012). Walkable City: How Downtown Can Save America, one step at a time. North New York, Point Press.

Khairi M. Al-bashir Abdulla, Mohamed Gamal Abdelmonem \& Gehan Selim. (2017). Walkability in historic urban spaces: testing the safety and security in Martyrs' Square in Tripoli. Archnet-IJAR: International Journal of Architectural Research, 11(3), 163177.

Leslie, E., Coffee, N., Frank, L., Owen, N., Bauman, A., \& Hugo, G. (2007). Walkability of local communities: using geographic information systems to objectively assess relevant environmental attributes. Health \& Place, 13(1), 111-122.

Lachapelle, U., Frank, L., Saelens, B.E., Sallis, J.F., Conway, T.L., (2009). Commuting by public transit and physical activity: where you live, where you work, and how you get there. Journal of physical activity \& health, 8, 1, 72-82.

Manaugh, K., \& El-Geneidy, A. (2011). Validating walkability indices: How do different households respond to the walkability of their neighbourhood? Transportation research Part D: Transport and Environment, 16(4), 309-315

Mayne, D.J., Morgan, G., Willmore, A., Rose, N., Jalaludin, B., Bambrick, H. \& Bauman, A. (2013). An objective index of walkability for research and planning in the Sydney Metropolitan Region of New South Wales, Australia: an ecological study. International Journal of Health Geographics, 12 (December), 61-1-61-10.

Morse, J.M. (1994). Designing funded qualitative research. In Denizin, N.K. \& Lincoln, Y.S., Handbook of qualitative research (2nd Ed). Thousand Oaks, CA: Sage.

Rachel Mundeli Murekatete \& Jean Pierre Bizimana. (2015). A GIS-based Aproach for Developing Urban Walkability Index: The Case of Kigali City, Rwanda. Geo Tech Rwanda 2015 - Kigali, 18-20 November 2015.

Tucker, P., Irwin, J.D., Gilliland, J., He, M., Larsen, K., Hess, P., (2009). Environmental influences on physical activity levels in youth. Health Place, 15, 357-363.

Zainol, R., Wang, C., Ali, A.S., Ahmad, F., Aripin, A.W.M., \& Salleh, H. (2016). Pedestrianization and walkability in a fast developing UNESCO world Heritage City. Open House International, 41(1), 112-119. 